\title{
Chapter 2 \\ Towards a Relational Anthropology \\ Fostering an Economics of Human Flourishing
}

\author{
Patrick Nullens and Jermo van Nes
}

\begin{abstract}
Basic capabilities and human interests that are directed towards the ideal of human flourishing now seem at odds with the concept of Homo economicus as once defined by John Stuart Mill - a rational being pursuing wealth only for his own self-interest. This popular paradigm still dominates economic theory and practice, but a growing group of academics consider its underlying model of human behavior to be inaccurate. As a result, scholars across various disciplines have expressed the need for a more refined anthropology in relation to contemporary economics. In response, the holistic concept of Homo amans as phenomenologically constituted by the virtues of faith, hope, and love is introduced, since multidisciplinary yet complementary study suggests that human persons are questing, expecting, and relational beings. Whether or not Homo amans could serve in the future as a complementary model to Homo economicus remains to be seen, because several aspects of human relationality that are relevant to contemporary economics are in need of future study.
\end{abstract}

\subsection{Introduction}

Amidst the many environmental and societal problems facing our world today, there is growing awareness and recognition in both academia and society that economics should aim to foster human well-being. But how do we substantiate the good life? Is it more than freedom of choice? Is it a matter of fulfilling our needs? Is it about commitment to an idea or ideal? The capability approach offers a potential way to move ahead. Inspired by the political/economic works of Amartya Sen (1992,

\footnotetext{
P. Nullens $(\varangle)$

Evangelische Theologische Faculteit, Leuven, Belgium

University for Humanistic Studies, Utrecht, The Netherlands

e-mail: Patrick.nullens@etf.edu

J. van Nes

Evangelische Theologische Faculteit, Leuven, Belgium

e-mail: Jermo.vannes@etf.edu
} 
1999), Martha Nussbaum (2011, pp. 33-34) proposed a list of ten core capabilities that will enable people to flourish. These are being able to (1) live, (2) enjoy good health, (3) move freely, (4) use the senses to imagine, think, and reason, (5) relate emotionally to things and people, (6) reason practically by engaging in critical reflection, (7) affiliate to others on the basis of self-respect and non-humiliation, (8) live in relation to the natural world, (9) play, and (10) have control over one's environment in terms of politics and property. In a similar vein, Christian Smith (2015, pp. 181-82) identified six universal goods that define basic human motivations and interests: (1) bodily survival, security, and pleasure, (2) knowledge of reality, (3) identity coherence and affirmation, (4) exercising purposive agency, (5) moral affirmation, and (6) social belonging and love. Without these, Smith (2015, p. 240) argues, no human being can develop: "[f]or persons to be rejected, excluded, and isolated, outcast, invisible, untouchable, and irrelevant, leaves them retarded, wounded, or deformed in their personhood." This implies that one can flourish as a person only by seeking the good for oneself and others, in other words, by seeking the common good.

Yet, in both academia and society the dominant approach to human behavior continues to be that of economic man or Homo economicus - "a model of human agency in which the individual actor maximizes his own well-being given the constraints he faces" (Rodriguez-Sickert 2009, p. 223). The term came into existence as late as 1883 (Devas 1883, p. 27), and though the concept can be traced all the way back to Xenophon of Athens (c. 430-355), it was the writings of the British theorists Adam Smith (1723-1790) and John Stuart Mill (1806-1873) that made the idea of Homo economicus popular and influential. ${ }^{1}$ While Smith $(1759,1776)$ developed a nuanced version of economic man whereby well-being is not exclusively related to material goods (McCloskey 2016, pp. 172-96), it was Mill (1844, p. 137) who defined Homo economicus as "a being who desires wealth, and who is capable of judging of the comparative efficacy of means for obtaining that end." Mill's focus on accumulation, leisure, luxury, and procreation, was to make his version of economic man the more popular and dominant one over time.

While the concept of economic man as introduced and developed by eighteenthand nineteenth-century British intelligentsia makes sense against the background of Enlightenment thinking in general, and the American Revolutionary War (1775-1783) as well as the French Revolution (1789-1799) in particular, it makes less sense today. The utilitarian model of behavior underlying this concept not only embodies a commitment to methodological individualism (i.e. the individual more than the social system is the basic unit of analysis), but also accepts that human nature is essentially rational, a-moral and unsocial (Bovenberg 2018, p. 25). However, from the twentieth century onwards, the mechanical worldview advocated by Mill (and his followers), in which people are isolated yet rational beings acting in an environment populated by like-minded individuals, has been criticized in many different disciplines (Kirchgässner 2008, pp. 185-218; Ng and Tseng 2008,

\footnotetext{
${ }^{1}$ For an historical overview of the concept of Homo economicus, see Hengstmengel (2020).
} 
pp. 269-71; Rodriguez-Sickert 2009, pp. 225-26; Klein 2011, pp. 101-109). Sociologists, for example, have insisted that the Homo economicus model is too narrow since it does not allow for human behavior to be explained by social norms (Dahrendorf 1958), social interdependence (Frank 1985), social relations (Granovetter 1985), moral codes (Sen 1982), and/or institutions (Bowles 1998). Behavioral economists (e.g. Forsythe et al. 1994; Gintis et al. 2005) have found that people sometimes act irrationally and/or reciprocally, something that goes beyond mere rational self-interest. More recently, neuroscientists have claimed that altruism is a genetically based human capacity (Krebs 2012). The same is true for emotions, which seems to affect human behavior (Haidt 2003). Because emotions "are generated spontaneously in the limbic system outside the conscious control of the individual" (Kullberg and Singer 2012, p. 249), they sometimes contradict the rationality of human nature.

With the concept of Homo economicus being criticized on so many fronts, ${ }^{2}$ Kate Raworth (2017, pp. 88-100) represents a growing group of scholars who have asked that Mill's caricature of human nature be replaced by a more refined anthropological model allowing for our sociality (instead of self-interest), fluid values (instead of fixed preferences), interdependency (instead of isolation), approximating (instead of calculating), and embeddedness in life (instead of dominion over life). ${ }^{3}$ As Raworth (2017, p. 82) urges,

...it is time to meet ourselves all over again by taking his [Mill's] cartoon depiction out of
the economic gallery and painting, in its place, a new portrait of humanity. It will turn out
to be the most important portrait commissioned in the twenty-first century, mattering not
just to economists but to us all. Its preparatory sketches are under way and, just as in
Leonardo's workshop, many artists are collaborating in piecing them together, from psy-
chologists, behavioral scientists and neurologists to sociologists, political scientists and,
yes, economists.

Yet responding to Raworth's call is anything but easy. Arguably the major challenge is finding a common language that enables scholars working in various disciplines, each with their own worldview and (religious) background, to think deeply about how human flourishing can be increased. This chapter is nothing more than a modest attempt to encourage a multidisciplinary dialogue on anthropology in contemporary economics by (1) rethinking human personhood, (2) introducing the concept of Homo amans as a complementary model to Homo economicus, and (3) exploring some dimensions of human relationality that deserve future study.

\footnotetext{
${ }^{2}$ For popular critiques on the Homo economicus model, see especially Cohen (2012), Papadogiannis (2014), and Fleming (2017). Already by 2000, a survey of 64 participants had revealed that even ordinary people question the model on the basis of common sense, as they generally believe that "the human being is free, changeable, influenced by the subjective world of experience, a product of the environment, and best understood from a holistic perspective" (Hochwälder 2000, p. 611).

${ }^{3}$ Other critics who have asked for the Homo economicus model to be replaced include Drucker (1939), Arendt (1958), Dahrendorf (1958), Elworthy (1993), O’Boyle (1994), Doucouliagos (1994), Bowles and Gintis (1998), Dinello (1998), Thaler (2000), Pearson (2000), and Girgerenzer and Brighton (2009), to name but a few.
} 


\subsection{What Is a Person? Rethinking Human Nature}

The centuries-old quest for the meaning of being human has given rise to many different and sometimes rival theories about human nature (Stevenson et al. 2018). Focusing on the Western intellectual tradition, Joseph Torchia (2008, p. xiii) distinguishes four distinct periods in the history of philosophical anthropology: (1) the classical period, ranging from the pre-Socratics to Aristotle, during which the first metaphysical accounts of humanity were developed; (2) the Middle Ages, when key Christian thinkers such as Augustine and Thomas argued for the fundamental psychosomatic unity and relationality of human beings; (3) Modernity, which saw the emergence of Descartes' mind-body dualism and the subsequent critique of the notion of mind in British empiricism as represented by David Hume; and (4) Postmodernity, during which a new brand of dualism emerged in terms of biological humanity versus moral personhood.

It appears that, during the long history of philosophical anthropology, the question of what it means to be human has been approached from different angles - the religious, the scientific, and the philosophical. Torchia (2008, p. 1) observes that from the very beginning two competing answers have been given, and these continue to be expressed in various forms: (1) teleological perspectives that endorse "a metaphysical distinction between an immaterial mind and a material body," recognizing "an order and a purposiveness in human existence by virtue of an appeal to something which transcends our physical being" (Torchia 2008, p. 1), and (2) mechanistic perspectives that ultimately reduce "our mental life and decision-making capacity to no more than highly complex neurophysiological processes", suggesting that "there is no difference between mind and brain, or between thinking and brainwave activity" (Torchia 2008, p. 1).

Drawing upon the works of the Scottish philosopher Alasdair MacIntyre (1981, 1988), Torchia (2008, p. 10) himself endorses the view that "only a teleological understanding of human nature and the virtuous life rooted in the Aristotelian/ Thomistic tradition of inquiry" allows for making moral judgments. This being the case, he stresses the importance of recovering a human telos to form the basis for our view of happiness. Accordingly, human lives are to be interpreted as coherent narratives directed toward the realization of their final ends. Torchia (2008, p. 11) questions whether "a purely reductionist account of human nature and personhood explain[s] everything we are capable of doing in cognitive, volitional, and affective terms." Personhood is not a matter of arbitrary interpretation, nor is it definable on the basis of biological or behavioral characteristics alone. Instead, Torchia (2008, p. 11) argues:

In my reckoning, "human being" is correlative with "being human," the mode of existence appropriate to persons as dynamic centers in their own right who participate in human nature even as they transcend it in their uniqueness. This touches on the mystery inherent in our way of being, a mystery that can only be revealed and appreciated by entering in the experience of the other through the intimacy of interpersonal relationships. In the face of such a penetrating mystery, a metaphysical explanation alone suffices, since this type of 
account attunes us to the luminosity of an inner life that always eludes attempts at complete empirical analysis.

Similarly, Christian Smith (2010) dismisses mechanistic anthropologies that reduce all reality to natural laws inherent in matter and energy and in doing so neglect the reality of moral values, meaning, and the spiritual dimension of life. Preferring a teleological understanding of human nature, Smith (2010, p. 15) argues "that human beings as they exist in the world embody a particular constitution they have a human nature rooted in nature more broadly." They are characterized by properties, abilities, and qualities that are unique to human personhood. Assuming the essentially social condition of humanity, Smith believes that human personhood emerges through the social interaction, communication, and communion between people. The concept of emergence is a daily phenomenon, referring to "the process of constituting a new entity with its own particular characteristics through the interactive combination of other, different entities that are necessary to create the new entity but that do not contain the characteristics present in the new entity" (Smith 2010, pp. 25-26). One could think, for instance, of hydrogen (H) and oxygen (O) merging into water $\left(\mathrm{H}_{2} \mathrm{O}\right)$.

In support of his thesis for the emergence of personhood, Smith relies on three key theoretical resources: (1) critical realism, (2) personalism, and (3) anti-scientistic phenomenology. First, critical realism as introduced by the English philosopher Roy Bhaskar (1997), searches for a middle way between empirical positivism on the one hand and postmodern constructivism on the other. It makes a distinction between the real, the actual, and the empirical: the real is the objective being, material or non-material, which exists apart from our human awareness of it; the actual is what happens in time and space, whether we experience it or not; and the empirical is what we experience directly and indirectly. Critical realism critiques the conflation of these three aspects. It is critically aware of our limited understanding and at the same time aware of a reality, apart from our limited understanding. Smith (2010, pp. 92-93) summarizes the core ideas of Bhaskarian critical realism as follows:

\footnotetext{
Critical realism's central organizing thought is that much of reality exists independently of human consciousness of it; that reality itself is complex, open, and stratified in multiple dimensions or levels ...; that humans can acquire a truthful, though fallible knowledge and understanding of reality through various forms of disciplined conceptualization, inquiry, and theoretical reflection; that (social) science is rightly concerned with, first, identifying what is real and, second, understanding and explaining real causal capacities, mechanisms, and processes that operate in reality to produce various events and outcomes of interest ... ; and, finally, that knowledge and understanding of the truths about reality position knowers to critically engage the world in normative, prescriptive, and even moral terms in ways that may overcome the traditional fact-value divide and intentionally try to shape the world for the better.
}

Being strongly anti-reductionistic, critical realism respects the many dimensions and causal interactions of what is real and actual. Smith (2010, p. 54) presents a list of no less than 30 human capacities that structure themselves hierarchically in five categories: (1) "existence capacities" (e.g. subconscious being), (2) "primary experience capacities" (e.g. mental representation), (3) "secondary experience 
capacities" (e.g. emotional experience), (4) "creating capacities" (e.g. language use), and (5) "highest order capacities" (e.g. interpersonal communion and love). To understand the interrelation of these capacities and to avoid all forms of reductionism, the reality of emergence is crucial. The 30 human capacities "are the stuff out of which human personhood exists emergently" (Smith 2010, p. 59).

Second, the core belief underlying the philosophy of personalism as it originated in the United States and continental Europe in the late nineteenth and early twentieth century respectively, is that human beings are real entities with an ontological being that exists in nature. We are truly persons. This ostensibly simple claim has serious implications as it entails that we are more than "rational, self-interested, exchange-making calculators of costs and benefits" (= Homo economicus); more than "the constituents of functional social orders"; more than "discursively constructed positions of shifting identities pieced together in the flux of variable meanings and power relations"; more than "corporeal sites through which regimes of power express themselves through bodily discipline"; more than "strategic, dramatic presenters of performances driven by culturally specified scripts"; more than "biological carriers of "selfish" genetic material that has been naturally selected upon for its superior reproductive fitness and that seeks to perpetuate itself through behavioral determinism"; and more than "egos struggling to manage the id in the face of the superego" (Smith 2010, pp. 102-103). Smith (2010, p. 104) approvingly quotes Karol Wojtyla (1993, p. 211), better known as Pope John Paul II, who notes that personalism believes "in the primordial uniqueness of the human being, and thus in the basic irreducibility of the human being to the natural world."

Third, anti-scientistic phenomenology as developed by the Canadian philosopher Charles Taylor (1989) challenges common assumptions of naturalistic scientism in terms of materialism, objectivity, and reductionism that discount "people's phenomenological experience as a guide to valid and reliable knowledge about reality, including human life" (Smith 2010, p. 105). Smith counters that no single scientific view should dominate, but that priority should be given to our lived experiences of being human. He argues that we are beings who want to make sense of our lives, because we are by nature morally and spiritually committed. We are always searching for "the best account" of our lives, referred to as "the BA [best account] principle" (Taylor 1989, p. 58). We need to search continuously for the best account that makes sense of our phenomenological experiences and immaterial realities, including value, meaning, morality, and personhood. Such accounts are best "arrived at by challenge, discussion, argumentation, reflection, criticism, vetting, that is, by testing against the clarity of experience, including through systematic observation and the discipline of reason" (Smith 2010, p. 112).

Smith also engages critically with the popular theory of social constructivism introduced by the sociologists Peter Berger and Thomas Luckmann (1966), who argued that all reality, including someone's personality, is socially constructed. This implies that what normally is taken for granted as "natural" and "factual" is nothing but a cultural artifact. As such, all theories regarding human nature, whether religious or scientific, are creations of people engaged in patterned roles and behaviors that become habituated or institutionalized. While Smith (2010, p. 121) recognizes 
that social constructivism is "an important instrument in the sociological toolkit," it overstretches relativistic claims when it becomes dominated by poststructuralism and postmodernism. By way of an alternative, Smith proposes a weak or realist version of social constructivism: "All human knowledge is conceptually mediated and can be and usually is influenced by particular and contingent sociocultural factors such as material interests, group structures, linguistic categories, technological development, and the like - such that what people believe to be real is significantly shaped not only by objective reality but also by their sociocultural contexts" (Smith 2010, p. 122). Yet these human capacities are not without limits. Human beings are finite creatures. It is in the tensions between human capacities and their limits that patterns of lived practice emerge, and eventually these become social structures. This entails that human goods or values are not conditional, and each society or individual is free to choose them.

All of these deliberations make Smith (2010, p. 61) define a human person as "a conscious, reflexive, embodied, bodied, self-transcending center of subjective experience, durable identity, moral commitment, and social communication who - as the efficient cause of his or her own responsible actions and interactions - exercises complex capacities for agency and intersubjectivity in order to develop and sustain his or her own incommunicable self in loving relationships with other personal selves and with the nonpersonal world" (Smith 2010, p. 61). He stresses that the fusion of these elements is not just a mix of component parts but constitutes a distinct personal being. This thick notion of human personhood grounds eudaimonic ethics, i.e. the understanding of the human good as the realization of our nature. Smith gives a foundation to a morality that profoundly acknowledges personal agency, sustaining a social context of loving and nurturing relationships that enable human persons to flourish. This involves an ethics that moves beyond a set of rules or procedures to a realistic type of teleological personalism: "Moral life that is tuned to reality thus begins with a correct understanding - whether intuitive or reflexive of the real human condition, actual human potentialities, and the right telos of personhood" (Smith 2010, p. 414). It requires virtue ethics "to become our real and best selves" (Smith 2010, p. 418). And for this purpose, no new moral system is needed; it simply requires the rediscovery of the wisdom of old moral systems that are already often in line with our own intuitions. Universal traits such as love, justice, generosity, etc., should be enacted and developed continuously. They enable us to flourish, and their absence from our lives threatens our very personhood.

\subsection{Faith, Hope, and Love: Introducing Homo Amans}

The studies of Torchia (2008) and Smith (2010), as outlined above, acknowledge the complexity of human nature and resist the reductionist tendencies in contemporary scholarship when defining human personhood. They both stress the importance of virtue. In the Judeo-Christian tradition, human personhood is marked, ideally, by the virtues of faith, hope, and love. They are mentioned in one breath by the apostle 
Paul in 1 Corinthians 13:13 - "And now faith, hope, and love abide, these three; and the greatest of these is love" (NRSV). Paul also notes that faith and love produce good works, and that hope gives endurance (cf. 1 Thess. 1:2-4); that faith, hope, and love are defensive weapons (cf. 1 Thess. 5:7-9); that faith is active in love (cf. Rom. 5:1-5; Gal. 5:5-6); and that faith and love are the result of hope (cf. Col. 1:4-6). Modern studies of the three theological virtues usually discuss them separately (e.g. Brunner 1956; Pieper 1986; Robinson 2004; Cubillos 2017), whereas ancient commentators stressed their inseparability. Augustine (Serm. 359A), for example, in one of his sermons noted: ${ }^{4}$

\begin{abstract}
Faith does not fail since it has hope to support it. Take away hope, and faith fails. How does someone who does not hope to arrive even move his feet in walking? But if from the two, faith and hope, you take away love, what good does it do to believe, what good does it do to hope? It is not possible to hope for what one does not love. It is love that kindles hope; hope glows with love. But when we have arrived at what we hoped for in faith without seeing it, what faith will be left to praise since faith is the conviction of things not seen [Hebr. 11:1]? When we see, it will no longer be called faith. You will see then; you won't believe. The same is true for hope itself. When the reality is present, you do not hope. For hope that is seen is not hope (Rom. 8:24). There it is: when we have arrived, faith is ended, hope is ended. What happens to love? Faith turns to sight and hope to its reality. Now it is sight and reality, not faith and hope. What happens to love? Can it come to an end? No, for if the soul was already aflame with love for what it had not seen, certainly when it sees this it will burn all the brighter. So it was truly said that the greatest of these is love, since faith is succeeded by sight, hope by reality, but love has no successor. It grows, it increases, it is perfected in contemplation.
\end{abstract}

The importance of the virtues of faith, hope, and love for human personhood is not stressed only in early Christian texts. In 2004, in the field of positive psychology, Christopher Peterson and Martin Seligman (2004) published a landmark crosscultural list of character strengths and virtues taken from different religious traditions (Confucianism, Taoism, Buddhism, Judeo-Christian, Islam) as well as from ancient and modern philosophy. ${ }^{5}$ They distinguish between virtues, character strengths, and situational themes. Virtues are "the core characteristics valued by moral philosophers and religious thinkers: wisdom, courage, humanity, justice, temperance, and transcendence;" character strengths are "the psychological ingredients" that form the routes to displaying virtues; and situational themes refer "to the specific habits that lead people to manifest given character strengths in given situations," such as the workplace or family (Peterson and Seligman 2004, pp. 13-14). The overall result revealed a surprising amount of similarity across cultures. Six core virtue groups were classified (wisdom and knowledge, humanity, courage, justice, temperance, and transcendence) that are based on 24 character strengths, including the capacity to love and to be loved, leadership, forgiveness and mercy, gratitude, hope, and religiousness and spirituality (Peterson and Seligman 2004, pp. 29-30). According to Peterson and Seligman (2004, p. 13), these virtues and character strengths are no social constructs, but universal predisposed mechanisms that are

\footnotetext{
${ }^{4}$ English translation of the Latin text is derived from Kovacs (2005, p. 228). Italics in original.

${ }^{5}$ See also http://www.viacharacter.org
} 
"grounded in biology through an evolutionary process that selected for these aspects of excellence as means of solving the important tasks necessary for survival of the species."

Similarly, Deirdre McCloskey (2006, pp. 91-300) in the field of economics argues that the virtues of faith, hope, and love (together with courage, temperance, justice, and prudence) are an integral part of the history of European prosperity, and continue to be essential for the well-functioning of a commercial society. They are classified as soft, "feminine" virtues that complement the overrated strong, "masculine" virtues of courage and prudence in the current world of markets. McCloskey (2006, pp. 168-171) rejects the anti-theistic bias of the French philosopher André Comte-Sponville (1995), who explicitly excludes faith and hope from his list of 18 great virtues since they have God as their object. He argues that courage will suffice in the presence of a danger or an uncertain future. McCloskey herself provides a secular version of faith, hope, and love in order to warrant their transcendent character. Faith is about our awareness of identity, "a backward-looking virtue" (McCloskey 2006, p. 153). Hope, by contrast, is "forward-looking" (McCloskey 2006, p. 160). Love is like "a commitment of the will to the true good of another," and has "the quality of attachment" (McCloskey 2006, p. 91).

When understood transcendently, the virtues of faith, hope, and love mark humans as questing, expecting, and relational beings. In the last decade, three major studies have argued that each trait is inherent in human nature. First, Wesley Wildman (2009) in a wide-ranging study offered a naturalistic interpretation of the human being as Homo religiosus. Integrating different academic disciplines, such as molecular biology, evolutionary theory, cognitive neurology, and the scientific study of religion, Wildman (2009, p. Xv) basically defended the hypothesis "that religious behaviors, beliefs, and experiences - understood sufficiently broadly - constitute human nature not only historically, culturally, or circumstantially, but also ontologically, essentially, and inescapably." He believes that religion is universal and applies even to atheistic scientists committed to the battle against the myths of religion and superstition. Religion is a commitment to ultimate and existential concerns as "[i]t pertains to the way we bind ourselves (religio) to that which has surpassing meaning for us," and, in this sense, "suffuses every aspect of human life" (Wildman 2009, p. $\mathrm{xv}$ ). Religion is not a cultural product, separate from our genes, but nor is it purely the result of evolutionary adaptation. In evolutionary terms, "religion," according to Wildman (2009, p. 69), "is as an ad hoc, complex, and variable assemblage of adapted and exapted genetic traits that constrain culturally colored exploration of a landscape of social and existential possibilities within an ultimate environment defined by the valuational depth of nature itself." This implies that human beings are religiously concerned in any given socio-cultural setting, but it does not require any verdict on the reality of god(s). It simply means that, by nature, we are all "oriented to primordial, ultimate mystery in our experiences, our social practices, our drives and projective impulses, our longings and failures, our malevolence and love" (Wildman 2009, p. 230).

Second, Anthony Scioli and Henry Biller (2009, p. 6) argued that the virtue of hope "is not merely a process by which you arrive at some desired destination," but 
also "a way of being in the world." Both psychologists insist that hope is a universal emotion, defining it as a "future-directed, four-channel emotion network, constructed from biological, psychological, and social resources" (Scioli and Biller 2009, p. 30). These four channels include mastery, attachment, survival, and spiritual subsystems that operate in semiautonomous fashion at five different levels in the life of every human person: (1) hope blueprints, which are "biologically based motives relating to mastery, attachment, and survival," (2) nature and nurture, consisting of "natural endowments and early nurturing experiences," (3) the hopeful core, including different "kinds of personality dispositions or traits" which emanate from the four-channel emotion network producing goal-related trust, mediated control, relational trust, self-other bonds, survival-oriented trust, terror management, spiritual integrity, and symbolic immortality, (4) the faith system, growing "from the seeds of trust, mediated control, and self-other bonds", and (5) beliefs and behaviors, which are "the manifestations or exterior signs of hope" (Scioli and Biller 2009, pp. 32-38). Scioli and Biller (2009, pp. 41-47) locate the origin of hope in the evolution of man, arguing that the construction of hope developed progressively, from 6,000,000 years ago when the first species possessed the pre-adaptations of hope until 2500 years ago when the grand religious, spiritual, and philosophical systems of the ancients originated. By that time, a form of brain reorganization had occurred that affected the mastery, attachment, and survival systems. According to Scioli and Biller (2009, p. 32), "there is overwhelming evidence that certain brain structures and pathways are primarily associated with these motives," pointing to, inter alia, the frontal lobes that allow "for mastery-associated initiative and planning," parts of the right hemisphere, the hormone oxytocin, and the amygdala that allow for "the biology of attachment", and the immune system as well as a complex set of reflexes and the stress-related "fight or flight response" that allow for our survival system.

Finally, Rebekka Klein (2011) described the sociality of the human condition. Acknowledging competing viewpoints in the study of anthropology, Klein (2011, p. 305) refrains from doing interdisciplinary study of anthropology as " $[t]$ he transdisciplinary way of gaining knowledge is rooted in the false premise that there is only one correct interpretation of human behaviour, and the best way to find this interpretation is to unify scientific methods and modes." Instead, she prefers to give primacy to philosophical anthropology by using a phenomenological method of multi-perspectivism that allows observers to describe objects from their own limited perspective. As Klein (2011, pp. 1-2) explains,

Phenomenological criticism is based on the intuition that the unique characteristics of an object of description show themselves precisely in the object's appearance, in its phenomenality to the observer. This applies to experiences in the lifeworld [Lebenswelt] as well as to the scientific analysis of an object. As a phenomenon, therefore, an object can never be described independently of the modality of its observation or description. Consequently, there can also be no perspective-free representation of the object in a phenomenological analysis that reduces the various aspects of its appearance to a single, supposedly more

${ }^{6}$ Italics in original. 
objective or more fundamental view. The multitude of appearances of an object is resistant to further analysis and cannot be resolved by interdisciplinary discourse or otherwise. Rather, it is the basic phenomenological task of an inter-disciplinary study to bring its individual perspectives to a point where they acknowledge that their representations are limited, and that they need to be supplemented with other perspectives regarding the phenomenality of their object.

So, Klein (2011, p. 3) urges that we should not seek to answer the question "What is a human being?" by means of empirical methods, but rather initiate a philosophical human self-inquiry by asking "What is human about human beings and their sociality?" She answers this question by offering a wide range of economic, philosophical, and theological perspectives (Klein 2011, pp. 27-301). She finds that human sociality is not found in the difference between human and animal sociality but in the every-day interactivity between human beings through which the humanity (and inhumanity) of human beings is displayed. Because the interactive relationship between human beings is vulnerable and critical, any description of human sociality should acknowledge the ambivalence in terms of "altruism/egoism, reconciliation/hostility, recognition/disrespect, responsibility for/negation of the other" (Klein 2011, p. 307). This anthropological tension is, in fact, acknowledged in theological perspectives, and described in terms of the old and new existence. From the perspective that God is present in the world, the old existence is replaced by the new existence. This entails that human beings become "a neighbour, 'a next one' to God," which makes it possible to explicate "the difference between the humanity and inhumanity of human social life" (Klein 2011, p. 307).

While using different methodologies, Wildman (2009), Scioli and Biller (2009), and Klein (2011) find respectively that we are questing, expecting, and relational beings. In terms of method, Klein's phenomenological analysis and theory of multiperspectivity allow for the complementarity of these three anthropological accounts. While the interrelationship of faith, hope, and love deserves future study, Scioli and Biller (2009) have indicated that faith is inspired by hope, and Wildman (2009) argued that love is inspired by faith. This aligns with the notion of Franz Foltz and Frederick Foltz (2018, p. 67) that "[f]aith and hope inform and inspire love." Supposing that the virtues of faith, hope, and love are somehow interconnected, we propose to invoke the holistic anthropological concept of Homo amans as a prescriptive category referring to man as a questing, expecting, and relational being. Unlike Mill's version of Homo economicus, the idea of Homo amans is inspired by ancient wisdom that aligns with contemporary scholarship and allows for three of our basic desires: (1) to quest for meaning (faith), (2) to project our desires onto the future (hope), and (3) to relate to other human beings (love): 


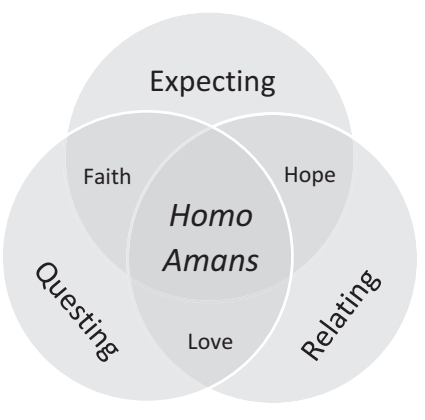

\section{4 "The Greatest of These is Love": Exploring Human Relationality}

Given the supremacy of love over faith and hope, the remainder of this chapter focuses specifically on our most important virtue. Love is a universal concept. It is present in all world religions (Greenberg 2008, p. xxiii). In the Qu'ran, for example, God is always spoken of as Al-Rahman ("the Compassionate One") and Al-Rahin ("the Merciful One"). Love as an ethics of reciprocity is expressed in the so-called golden rule "do unto others as you would have them do unto you," which has universal support in virtually all societies (Hertzler 1934). Yet this does not mean that love is understood everywhere in the same way. The ancient Greeks, for example, distinguished between eros, philia, and agape. It is often said that these concepts referred to sexual, brotherly, and divine love respectively (e.g. Nygren 1969; Greenberg 2008, p. xxiii), but this does not find support in all ancient sources (Silva 2014a, p. 112, 2014b, p. 606): eros is associated with good things, virtues, perseverance and temperance, peace, truth, wisdom, heavenly, divine, and even the source of all virtue (e.g. Philo, Leg. 2.55,80,83; Somn. 2.40; Spec. 2.258; Virt. 1.55,62); philia is used in reference to political alliances (e.g. Josephus, Ant. 7.66; 12.154), seduction (e.g. Sir. 9.8), and the divine-human relationship (John 5:20, 16:27; Philo, Fug. 58; Cont. 90); and agape connotes sexual love (e.g. Prov. 2:4-7).

Semantic ambiguity in the vocabulary of love exposes the need for a sound definition. Yet as Edward Vacek (1994, p. 34) observed, "most philosophical and theological writing, when it speaks of 'love', does not analyze what love is, but rather assumes that it has an evident meaning." Vincent Brümmer (1993, pp. 39-146), being one of the exceptions, distinguishes five attitudinal forms of love, three of which are directed towards beloved persons (exclusive attention, ecstatic union, and passionate suffering) and two of which are directed towards persons in general (need-love and gift-love). Brümmer himself concludes that love is a relationship more than an attitude, arguing that all five attitudinal forms of love are somehow involved in this relationship. The relational nature of love is also reflected in the definition given by Thomas Oord (2010, p. 15): "To love is to act intentionally, in 
sympathetic response to others (including God), to promote overall well-being." Or, in other words, "loving actions are influenced by the previous actions of others, oneself, and God, and these actions are purposefully executed in the hope of encouraging flourishing" (Oord 2010, p. 15).

Not everyone will agree with Oord's definition. Evolutionary biologists will probably refer to Richard Dawkins' influential thesis $(2016$, p. 3) that we are blind to our motives because our genes are essentially selfish as they are "programmed" for reproduction:

[W]e, and all other animals, are machines created by our genes... [A] predominant quality to be expected in a successful gene is ruthless selfishness. This gene selfishness will usually give rise to selfishness in individual behavior. However, ... there are special circumstances in which a gene can achieve its own selfish goals by fostering a limited form of altruism at the level of individual animals. [...] Much as we might wish to believe otherwise, universal love and the welfare of the species as a whole are concepts that simply do not make evolutionary sense.

In other words, someone cannot act for the well-being of others without some form of selfish motivation or genetic programming for personal benefit. This makes the intentional act of love and common aim for well-being questionable. Dawkins' theory, however, is not immune to criticism (McGrath 2007). Even our day-to-day experience of people acting benevolently towards others without receiving anything in return challenges Dawkins' theory. This is why Edward Wilson (1975, p. 3) once considered altruism "the central theoretical problem of sociobiology", asking "how ... altruism, which by definition reduces personal fitness, [can] possibly evolve by natural selection." One solution that has been proposed is that helping others has personal benefits in the end as it helps a species to survive. As Samuel Bowles and Herbert Gintis (2011, p. 1) explain, "people cooperate not only for selfinterested reasons but also because they are genuinely concerned with the wellbeing of others, try to uphold social norms, and value behaving ethically for its own sake" on the basis that "our ancestors lived in environments ... in which groups of individuals who were predisposed to cooperate and uphold ethical norms tended to survive and expand relative to other groups."

For Paul Seabright (2010), this new perspective on human evolution implies that we are cognitively and temperamentally adapted to intimate world cooperation. In the Holocene period, which started about 12,000 years ago, human life became less mobile and was based more on farming. People started to live in less intimate worlds, culminating in more complex social worlds of large-scale states and cities. How did minds, customs, and social technologies adapted to these intimate worlds support cooperation? If humans were to thrive in a more densely populated environment, the circle of cooperation would somehow have to be enlarged. This is how trust in non-intimates became a major issue. The profit in cooperating was dependent on the trustworthiness of others. This makes Seabright wonder how the human species made the transition some 12,000 years ago from "murder that stranger" to "smile at that stranger." Paul Frijters and Gigi Foster (2013) affirm that love is a product of evolution in accordance with elementary desires and basic mental processes, but they also think that this was not a conscious decision. In fact, Frijters and 
Foster (2013, p. 88) believe that love is ultimately ego-centric, since the unconscious is prone to believe in reciprocity and thus will "implicitly believe that the entity to which [it is] giving [its] love will reciprocate."

Amidst the confusion about our selfish, cooperative, and altruistic behavior, evolutionary psychologist Dennis Krebs (2012, p. 36) helpfully distinguishes between two types of altruism - "one defined in terms of the consequences of helping behaviors, and the other in terms of the motives and intentions of those who help others." He thinks the former type is biologically selfish, while the latter is not. This makes us partly selfish and partly altruistic by nature. Evidence for the latter was initially provided by social psychologists in the 1970s and 1980s. As Jane Allyn Piliavin and Hong-Wen Charng (1990, p. 27) noted in their literature review of 1990, the "theory and data now being advanced are more compatible with the view that true altruism acting with the goal of benefitting another - does exist and is a part of human nature." More recently, the findings of neurologists seem to support this conclusion (e.g. Eisenberger 2013; Vrtička 2017). Donald Pfaff (2015) outlined his altruistic brain theory, explaining how neurons in our prefrontal cortex are naturally inclined to make us behave altruistically. For Pfaff $(2015$, p. 10), "the guiding principle of a healthy human brain is 'First act morally, then ask why'." If people are basically good, he argues, empathy and trust are of enormous practical utility since they are crucial to all sorts of relationships in private and public life. Trust is encouraged by good behavior and this in turn encourages team spirit, as people are willing to rely on each other. When all members of a group hold each other in high regard, their cooperation will produce a positive outcome. Pfaff offers a piece of advice to society on the basis of his altruistic brain theory: remove all obstacles to leadership by women, because "[w]omen's hormones, such as estrogen and oxytocin operating on circuits in the female brain, together with the neural systems they affect, foster prosocial attitudes and good behavior" (Pfaff 2015, p. 264).

For at least three reasons, Pfaff's work is of great significance for economic theory and practice, especially leadership studies. First, it accredits the shift from transactional to (authentic) transformational leadership as being partly motivated by a growing number of behavior studies showing that interest in others motivates us more than self-interest (Bass and Steidlmeier 1999). Second, altruistic leadership theories, such as Servant Leadership (Greenleaf 2002), Responsible Leadership (Pless and Maak 2012) and Spiritual Leadership (Fry 2003), are encouraged to use the notion of trust in rethinking the critical relation between self-love and other-love in terms of cooperation. By way of example, Geoff Moore (2017) recently promoted virtuous leadership in companies and organizations. Distinguishing between internal goods ("goods which we should pursue for their own sake", e.g. love) and external goods ("[goods] which we should pursue for the sake of some other good," e.g. economic success), Moore (2017, p. 59) argues that managers have a specific role to play in upholding the tension between both types of goods in order to establish cooperation between employers and employees. Third, Pfaff's work aligns with McCloskey's notion that love is a feminine virtue. Its findings affirm the importance of moral exemplars, in particular women, because they spark prosocial behavior. As James Van Slyke (2014, p. 476) notes: 
Moral exemplars are persons whose appraisal systems are uniquely attuned to the moral life and are able to know the correct moral action based on intuitive processes running in parallel and linked with other types of evaluation. Over time, these evaluations produce good moral actions that require less and less conscious deliberation and become dispositions towards right moral action. These dispositions become the basis of moral character and generate consistency and reliability in moral action.

Because moral exemplars embody love on a regular and consistent basis, we normally want to imitate them. Thomas Oord (2013, p. 187) suggested that, after determining what criteria should be used, a research program be undertaken to compare the neural systems of moral exemplars with people who did not develop loving characters. In such a program, it would also be interesting to examine if it would make any difference to the results if the (non-)moral exemplars were religious or not. One would expect confessing believers as imitators of their superior moral exemplars (e.g. Jesus, Buddha) to show a more loving character, but the current state of the art cannot confirm that there is a positive correlation between altruism and religion (Habito and Inaba 2008, pp. 4-5).

Our natural inclination to do good, and the very existence of exemplars that embody, inter alia, the virtue of love, raises the question of what factors make people develop into such exemplars. Focusing on moral development in early childhood, Robert Emde (2016) assumes virtues to be universal, social, emotion-motivated, polar, and developing over time. Because human behavioral development involves necessary adaptive exchanges within the environment, it must be considered in both its biological and sociocultural context, i.e. "not only from the perspective of continuity, but from the perspective of transformational change; not only from the perspective of successful adaptation and health, but from the perspective of unsuccessful adaptation and disorder" (Emde 2016, p. 71). Key to the formation of the social self in early childhood, according to Emde, are (1) reciprocity (e.g. turn-taking, fairness), (2) empathy (e.g. emotional communication, compassion), and (3) valuation (e.g. the internalization of rules and standards). Each of these dimensions should be supported by parental regulation in order to prevent the moral development of infants from going awry. With regards to this possibility, Emde (2016, p. 83) stresses that future study is needed on why morally virtuous people, at any age, turn "to what most would see as the dark side, and what overcomes such turnings" as well as "the prevention of derailment of individual pathways to what most in a society would consider virtuous."

Emde's study exposes our current ignorance about the specifics of the social circumstances that help people maintain virtue, including love. This applies not only to people of different age-groups, such as children, teenagers, adults, the elderly, etc., but also to people acting in different contexts, such as home, school, work, etc. While Emde stressed the importance of parents acting reciprocally, empathetically, and evaluatively at home in order to encourage virtuous living among their children, Lans Bovenberg (2016) in his inaugural lecture at Tilburg University some years ago argued that education informed by a relational anthropology will create more awareness of citizenship among teenagers. According to Bovenberg, economics is not only about earning money but also about building relationships. 
He stresses the importance of finding the right balance in serving one's own needs and those of others. While people will always make mistakes in this process, the overall purpose should be to cooperate in a reciprocal way that eventually gives the best result for all stakeholders involved. In terms of work, Stephen Post and Jill Neimark (2007) encourage organizations to foster a "positive hierarchy," where an ethos of service emanates from the top down and reciprocal behavior is expected, exhorted, acknowledged, and rewarded. These are just examples of how moral development can be supported in the contexts of home, school, and work, but it is to be expected that many more could be discovered for similar and other contexts. One could question, for example, whether companies should offer bonuses to reward their employees for their profit making or their (reciprocal) behavior.

A final thought concerns the future of human relationality in an age of technology. According to Foltz and Foltz (2018, p. 128), the technical revolution reduces loving actions to rational processes and single operations. Yuval Noah Harari (2016, p. 388) warns about dataism that only appraises "the value of human experiences according to their function in data-processing mechanisms." While not necessarily due to technological developments, a 2006 report from the American Sociology Review (McPherson et al. 2006) showed that the number of friends for the average American over the period 1985-2004 dropped from 4 to 2. The number of digital friends via networks such as Facebook will have increased, but this is not without negative psychological and relational experiences (Fox and Moreland 2015). These are only some examples of how technology could have negative effects on human relationality, but there are also examples of positive use of technology in this regard. Social neuroscientists, for example, have developed compassion training programs for people lacking empathy, one of which trains people to have more compassion by means of, inter alia, simulated video games (Leiberg et al. 2011).

\subsection{Discussion}

A growing body of evidence across various academic disciplines shows that human beings do not behave in an exclusively selfish way. This means that the concept of Homo economicus is in need of serious modification. By way of suggestion, we have introduced the concept of Homo amans - a holistic anthropological model that is phenomenologically constituted by the virtues of faith, hope, and love and refers to man as a questing, expecting, and relational being who wants to foster human flourishing. Whether or not Homo amans could serve in the future as a complementary model to Homo economicus remains to be seen, because several aspects of human relationality in relation to contemporary economics are contested and in need of future study. The following questions might shape a future multidisciplinary dialogue on relational anthropology:

1. How is love best defined, and how does it relate to other virtues in general, as well as faith and hope in particular? 
2. Are we naturally predisposed to love, and if so, how does this generate trust?

3. Is there any connection between trust and the virtues of faith, hope, and love, and if so, how are they interconnected?

4. How can the virtue of love develop over a person's life-time, and what factors encourage people to promote well-being in the contexts of home, school, and work?

5. Which areas of the neural system are required to facilitate a person acting intentionally to promote overall well-being?

6. Does gender make any difference to the promotion of well-being in companies and organizations?

7. How is love understood inter-culturally and inter-religiously in relation to global economics?

8. How can technology damage and stimulate human relationality in the future?

\section{References}

Arendt, H. 1958. The Human Condition. Chicago: The University of Chicago Press.

Bass, B., and P. Steidlmeier. 1999. Ethics, Character, and Authentic Transformational Leadership Behavior. The Leadership Quarterly 10 (2): 181-217.

Berger, P.L., and T. Luckmann. 1966. The Social Construction of Reality: A Treatise in the Sociology of Knowledge. New York: Doubleday.

Bhaskar, R. 1997. A Realist Concept of Science. London: Verso.

Bovenberg, A.L. 2016. Economieonderwijs in balans: kiezen en samenwerken. Tilburg: Tilburg University.

- 2018. Economics as a Discipline of Hope. In Driven by Hope: Economics and Theology in Dialogue, ed. S.C. van den Heuvel and P. Nullens, 21-48. Leuven: Peeters.

Bowles, S. 1998. Endogenous Preferences: The Cultural Consequences of Markets and Other Economic Institutions. Journal of Economic Literature 36 (1): 75-111.

Bowles, S., and H. Gintis. 1998. Is Equality Passé? Homo Reciprocans and the Future of Egalitarian Politics. Boston Review 23 (6): 1-27.

-2011. A Cooperative Species: Human Reciprocity and Its Evolution. Princeton/Woodstock: Princeton University Press.

Brümmer, V. 1993. The Model of Love: A Study in Philosophical Theology. Cambridge: Cambridge University Press.

- 1956. Faith, Hope, and Love. Philadelphia: The Westminster Press.

Cohen, D. 2012. Homo Economicus: Prophète (égaré) des temps nouveaux. Paris: Michel.

Comte-Sponville, A. 1995. Petit traité des grandes vertus. Paris: Presses Universitaires de France.

Cubillos, R.H. 2017. Faith, Hope, and Love in the Kingdom of God. Eugene: Pickwick.

Dahrendorf, R. 1958. Homo Sociologicus: Ein Versuch zur Geschichte, Bedeutung und Kritik der Kategorie der sozialen Rolle. Cologne/Opladen: Westdeutscher Verlag.

Dawkins, R. 2016. The Extended Selfish Gene. Oxford: Oxford University Press.

Devas, C.S. 1883. Groundwork of Economics. London: Longmans, Green \& Co.

Dinello, N. 1998. Russian Religious Rejections of Money and "Homo Economicus": The SelfIdentifications of the "Pioneers of a Money Economy" in Post-Soviet Russia. Sociology of Religion 59 (1): 45-64.

Doucouliagos, C. 1994. A Note on the Evolution of Homo Economicus. Journal of Economic Issues 28 (3): 877-883.

Drucker, P. 1939. The End of Economic Man: The Origins of Totalitarianism. New York: Day. 
Eisenberger, N.I. 2013. Social Ties and Health: A Social Neuroscience Perspective. Current Opinion in Neurobiology 23 (3): 407-413.

Elworthy, C. 1993. Homo Biologicus: An Evolutionary Model for the Human Sciences. Berlin: Duncker \& Humblot.

Emde, R.N. 2016. From a Baby Smiling: Reflections on Virtues in Development. In Developing the Virtues: Integrating Perspectives, ed. J. Annas, D. Narvaez, and N.E. Snow, 69-94. New York: Oxford University Press.

Fleming, P. 2017. The Death of Homo Economicus: Work, Debt and the Myth of Endless Accumulation. London: Pluto Press.

Foltz, F.A., and F.A. Foltz. 2018. Faith, Hope, and Love in the Technological Society. Eugene: Cascade.

Forsythe, R., J.L. Horowitz, N.E. Savin, and M. Sefton. 1994. Fairness in Simple Bargaining Experiments. Games and Economic Behavior 7 (3): 346-380.

Fox, J., and J.J. Moreland. 2015. The Dark Side of Social Networking Sites: An Exploration of the Relational and Psychological Stressors Associated with Facebook Use and Affordances. Computers in Human Behavior 45 (4): 168-176.

Frank, R.H. 1985. Choosing the Right Pond: Human Behavior and the Quest for Status. Oxford: Oxford University Press.

Frijters, P., and G. Foster. 2013. An Economic Theory of Greed, Love, Groups, and Networks. Cambridge: Cambridge University Press.

Fry, L.W. 2003. Toward a Theory of Spiritual Leadership. The Leadership Quarterly 14 (6): 693-727.

Gintis, H., S. Bowles, R. Boyd, and E. Fehr, eds. 2005. Moral Sentiments and Material Interests: The Foundations of Cooperation in Economic Life. Cambridge, MA: MIT Press.

Girgerenzer, G., and H. Brighton. 2009. Homo heuristicus: Why Biased Minds Make Better Inferences. Topics in Cognitive Science, 1(1), 107-143.

Granovetter, M. 1985. Economic Action and Social Structure: The Problem of Embeddedness. American Journal of Sociology 91 (3): 481-510.

Greenberg, Y.K. 2008. Encyclopedia of Love in World Religions. Santa Barbara/Denver/Oxford: ABC-CLIO.

Greenleaf, R.K. 2002. Servant Leadership: A Journey into the Nature of Legitimate Power and Greatness. New York: Paulist Press.

Habito, R.L.F., and K. Inaba, eds. 2008. The Practice of Altruism: Caring and Religion in Global Perspective. Newcastle: Cambridge Scholars Press.

Haidt, J.D. 2003. The Moral Emotions. In Handbook of Affective Sciences, ed. R.J. Davidson, K.R. Scherer, and H.H. Goldsmith, 852-870. Oxford: Oxford University Press.

Harari, Y.N. 2016. Homo Deus: A Brief History of Tomorrow. London: Secker.

Hengstmengel, J. 2020. De Homo Economicus: Een familiegeschiedenis. Amsterdam: Boom.

Hertzler, J.O. 1934. On Golden Rules. The International Journal of Ethics 44 (4): 418-436.

Hochwälder, J. 2000. Assumptions about Human Nature: Comparison of Implicit and Explicit Personality Theories. Psychological Reports 87 (2): 611-622.

Kirchgässner, G. 2008. Homo Oeconomicus: The Economic Model of Behaviour and Its Applications in Economics and Other Social Sciences. New York: Springer.

Klein, R.A. 2011. Sociality as the Human Condition: Anthropology in Economic, Philosophical, and Theological Perspective. Transl. M. Sitling. Leiden/Boston: Brill.

Kovacs, J.L. 2005. 1 Corinthians Interpreted by Early Christian Commentators. Grand Rapids/ Cambridge: Eerdmans.

Krebs, D.L. 2012. How Altruistic by Nature? In Moving Beyond Self-Interest: Perspectives from Evolutionary Biology, Neuroscience, and the Social Sciences, ed. S.L. Brown, R.M. Brown, and L.A. Penner, 25-38. Oxford: Oxford University Press.

Kullberg, J.S., and J.D. Singer. 2012. Bringing Neuroscience into Political Science: The Caregiving System and Human Sociopolitical Evolution. In Moving Beyond Self-Interest: Perspectives from Evolutionary Biology, Neuroscience, and the Social Sciences, ed. S.L. Brown, R.M. Brown, and L.A. Penner, 246-268. Oxford/New York: Oxford University Press. 
Leiberg, S., O. Klimecki, and T. Singer. 2011. Short-term Compassion Training Increases Prosocial Behavior in a Newly Developed Prosocial Game. PloS One 6 (3): e17798.

MacIntyre, A. 1981. After Virtue: A Study in Moral Theory. Notre Dame: University of Notre Dame Press.

- 1988. Whose Justice? Which Rationality? Notre Dame: University of Notre Dame Press.

McCloskey, D.N. 2006. The Bourgeois Virtues: Ethics for an Age of Commerce. Chicago/London: The University of Chicago Press.

- 2016. Bourgeois Equality: How Ideas, Not Capital or Institutions, Enriched the World. Chicago/London: The University of Chicago Press.

McGrath, A. 2007. Dawkins' God: Genes, Memes, and the Meaning of Life. Oxford: Blackwell.

McPherson, M., L. Smith-Lovin, and M.E. Brashears. 2006. Social Isolation in America: Changes in Core Discussion Networks over Two Decades. American Sociology Review 71 (3): 353-375.

Mill, J.S. 1844. Essays on Some Unsettled Questions of Political Economy. London: Parker.

Moore, G. 2017. Virtue at Work: Ethics for Individuals, Managers, and Organizations. Oxford: Oxford University Press.

Ng, I.C.L., and L.M. Tseng. 2008. Learning to be Sociable: The Evolution of Homo Economicus. The American Journal of Economics and Sociology 67 (2): 265-286.

Nussbaum, M.C. 2011. Creating Capabilities: The Human Development Approach. Cambridge, MA/London: Harvard University Press.

Nygren, A. 1969 [1938]. Agape and Eros. Transl. P.S. Watson. New York: Harper \& Row.

O'Boyle, E. 1994. Homo Socio-Economicus: Foundational to Social Economics and the Social Economy. Review of Social Economy, 52(3), 286-313.

Oord, T.J. 2010. Defining Love: A Philosophical, Scientific, and Theological Engagement. Grand Rapids: Brazos.

- 2013. Types of Love and Types of Exemplars: Implications for Virtue Science. In Theology and the Science of Moral Action: Virtue Ethics, Exemplarity, and Cognitive Neuroscience, ed. J.A. Van Slyke et al., 179-190. New York/London: Routledge.

Papadogiannis, Y. 2014. The Rise and Fall of Homo Economicus: The Myth of the Rational Human and the Chaotic Reality. North Charleston: CreateSpace.

Pearson, H. 2000. Homo Economicus Goes Native. 1859-1945: The Rise and Fall of Primitive Economics. History of Political Economy, 32(4), 933-989.

Peterson, C., and M.E.P. Seligman. 2004. Character Strengths and Virtues: A Handbook and Classification. Oxford/New York: Oxford University Press.

Pfaff, D.W. 2015. The Altruistic Brain: How We Are Naturally Good. New York: Oxford University Press.

Pieper, J. 1986. Lieben, Hoffen, Glauben. Munich: Kösel.

Piliavin, J.A., and H.-W. Charng. 1990. Altruism: A Review of Recent Theory and Research. Annual Review of Sociology 16: 27-65.

Pless, N.M., and T. Maak. 2012. Responsible Leadership: Pathways to the Future. In Responsible Leadership, ed. N.M. Pless and T. Maak, 3-13. Dordrecht: Springer.

Post, S., and J. Neimark. 2007. Why Good Things Happen to Good People: The Exciting New Research That Proves the Link Between Doing Good and Living a Longer, Healthier, Happier Life. New York: Broadway.

Raworth, K. 2017. Doughnut Economics: Seven Ways to Think Like a 21st Century Economist. White River Junction: Green.

Robinson, E.A. 2004. These Three: The Theological Virtues of Faith, Hope, and Love. Eugene: Wipf \& Stock.

Rodriguez-Sickert, C. 2009. Homo economicus. In Handbook of Economics and Ethics, ed. J. Peil and I. van Staveren, 223-229. Cheltenham/Northampton: Elgar.

Scioli, A., and H.B. Biller. 2009. Hope in the Age of Anxiety: A Guide to Understanding and Strengthening Our Most Important Virtue. Oxford/New York: Oxford University Press.

Seabright, P. ${ }^{2} 2010$. The Company of Strangers: A Natural History of Economic Life. Princeton/ Oxford: Princeton University Press. 
Sen, A.K. 1982. Choice, Welfare, and Measurement. Oxford: Blackwell.

. 1992. Inequality Reexamined. New York/Cambridge, MA: Russell Sage Foundation/ Harvard University Press. 1999. Development as Freedom. Oxford: Oxford University Press.

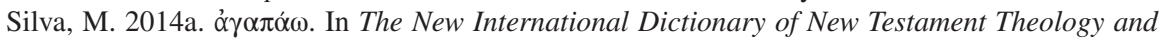
Exegesis, ed. M. Silva, vol. Vol. 1, 103-115. Grand Rapids: Zondervan.

- 2014b. $\varphi \imath \lambda \dot{\varepsilon} \omega$. In The New International Dictionary of New Testament Theology and Exegesis, ed. M. Silva, vol. Vol. 4, 605-608. Grand Rapids: Zondervan.

Smith, A. 1759. The Theory of Moral Sentiments. London: Millar, Kincaid \& Bell.

- 1776. An Inquiry into the Nature and Causes of the Wealth of Nations (2 vols.). London: Strahan \& Cadell.

Smith, C. 2010. What is a Person? Rethinking Humanity, Social Life, and the Moral Good from the Person Up. Chicago/London: The University of Chicago Press.

- 2015. To Flourish or Destruct: A Personalist Theory of Human Goods, Motivations, Failure, and Evil. Chicago/London: The University of Chicago Press.

Stevenson, L., D.L. Haberman, P.M. Wright, and C. Witt. 2018. Thirteen Theories of Human Nature. New York/Oxford: Oxford University Press.

Taylor, C. 1989. Sources of the Self: The Making of the Modern Identity. Cambridge, MA: Harvard University Press.

Thaler, R.H. 2000. From Homo Economicus to Homo Sapiens. Journal of Economic Perspectives 14 (1): 133-141.

Torchia, J. 2008. Exploring Personhood: An Introduction to the Philosophy of Human Nature. Lanham: Rowman \& Littlefield.

Vacek, E.C. 1994. Love, Human and Divine: The Heart of Christian Ethics. Washington, DC: Georgetown University Press.

Van Slyke, J.A. 2014. Moral Psychology, Neuroscience, and Virtue: From Moral Judgment to Moral Character. In Virtues and Their Vices, ed. K. Timpe and C.A. Boyd, 459-480. Oxford: Oxford University Press.

Vrtička, P. 2017. The Social Neuroscience of Attachment. In Neuroscience and Social Science: The Missing Link, ed. A. Ibáñez, L. Sedeño, and A.M. García, 95-120. New York: Springer.

Wildman, W.J. (2009). Science and Religious Anthropology: A Spiritually Evocative Naturalist Interpretation of Human Life. Aldershot: Ashgate.

Wilson, E.O. 1975. Sociobiology: The New Synthesis. Cambridge, MA/London: Harvard University Press.

Wojtyla, K. 1993. Person and Community. Transl. T. Sandok. New York: Lang. 
Open Access This chapter is licensed under the terms of the Creative Commons Attribution 4.0 International License (http://creativecommons.org/licenses/by/4.0/), which permits use, sharing, adaptation, distribution and reproduction in any medium or format, as long as you give appropriate credit to the original author(s) and the source, provide a link to the Creative Commons license and indicate if changes were made.

The images or other third party material in this chapter are included in the chapter's Creative Commons license, unless indicated otherwise in a credit line to the material. If material is not included in the chapter's Creative Commons license and your intended use is not permitted by statutory regulation or exceeds the permitted use, you will need to obtain permission directly from the copyright holder. 